\title{
The global effect of follicle-stimulating hormone and tumour necrosis factor a on gene expression in cultured bovine ovarian granulosa cells
}

\author{
Claire Glister ${ }^{1}$, Nicholas Hatzirodos ${ }^{2}$, Katja Hummitzsch², Philip G Knight ${ }^{1}$ and Raymond J Rodgers ${ }^{2 *}$
}

\begin{abstract}
Background: Oocytes mature in ovarian follicles surrounded by granulosa cells. During follicle growth, granulosa cells replicate and secrete hormones, particularly steroids close to ovulation. However, most follicles cease growing and undergo atresia or regression instead of ovulating. To investigate the effects of stimulatory (follicle-stimulating hormone; FSH) and inhibitory (tumour necrosis factor alpha; TNFa) factors on the granulosa cell transcriptome, bovine ovaries were obtained from a local abattoir and pools of granulosa cells were cultured in vitro for six days under defined serum-free conditions with treatments present on days 3-6. Initially dose-response experiments $(n=4)$ were performed to determine the optimal concentrations of FSH $(0.33 \mathrm{ng} / \mathrm{ml})$ and TNFa $(10 \mathrm{ng} / \mathrm{ml})$ to be used for the microarray experiments. For array experiments cells were cultured under control conditions, with FSH, with TNFa, or with FSH plus TNFa ( $n=4$ per group) and RNA was harvested for microarray analyses.

Results: Statistical analysis showed primary clustering of the arrays into two groups, control/FSH and TNFa/TNFa plus FSH. The effect of TNFa on gene expression dominated that of FSH, with substantially more genes differentially regulated, and the pathways and genes regulated by TNFa being similar to those of FSH plus TNFa treatment. TNFa treatment reduced the endocrine activity of granulosa cells with reductions in expression of FST, INHA, INBA and $A M H$. The top-ranked canonical pathways and GO biological terms for the TNFa treatments included antigen presentation, inflammatory response and other pathways indicative of innate immune function and fibrosis. The two most significant networks also reflect this, containing molecules which are present in the canonical pathways of hepatic fibrosis/hepatic stellate cell activation and transforming growth factor $\beta$ signalling, and these were up regulated. Upstream regulator analyses also predicted TNF, interferons $\gamma$ and $\beta 1$ and interleukin $1 \beta$.

Conclusions: In vitro, the transcriptome of granulosa cells responded minimally to FSH compared with the response to TNFa. The response to TNFa indicated an active process akin to tissue remodelling as would occur upon atresia. Additionally there was reduction in endocrine function and induction of an inflammatory response to TNFa that displays features similar to immune cells.
\end{abstract}

Keywords: Ovary, Microarray analysis, Bovine granulosa cells, Follicles

\section{Background}

An ovarian primordial follicle is composed of an inactive oocyte surrounded by granulosa cells all enclosed by a basal lamina. The granulosa cells of the ovarian follicle support and nurture the oocyte, and secrete oestrogens which are necessary for normal reproductive function.

\footnotetext{
* Correspondence: ray.rodgers@adelaide.edu.au

${ }^{2}$ Discipline of Obstetrics and Gynaecology, School of Paediatrics and Reproductive Health, Robinson Institute, University of Adelaide, 5005 Adelaide, SA, Australia

Full list of author information is available at the end of the article
}

In mammals, the latter stage of follicle development can involve an approximate hundred fold increase in diameter, 21 doublings of granulosa cell numbers [1] and formation of a fluid-filled antrum [2]. In cattle, the growth of follicles is tightly regulated, since two or three groups or waves of follicles emerge from a pool of follicles larger than $5 \mathrm{~mm}$ in diameter during each oestrous cycle $[3,4]$. In these waves, follicles continue to enlarge over several days until one follicle grows faster and larger than the others and hence gains 'dominance' $[5,6]$. This deviation in size occurs when the follicles are around

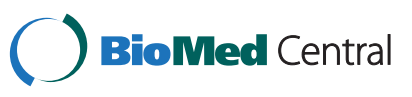


7-8 $\mathrm{mm}$ in diameter [7]. These processes of follicular growth occur largely due to the stimulatory influence of $\mathrm{FSH}$, through its receptor localised exclusively to the granulosa cells, though other factors produced locally, for example Growth Differentiation Factor (GDF)-9 [8] and Bone Morphogenetic Protein (BMP)-15 from the oocyte [9], are also involved.

Instead of one primordial follicle growing to ovulatory size and then ovulating, many follicles commence growing during the course of the cycle. Most of these growing follicles become atretic, resulting in cows and humans, in only one or occasionally two follicles ovulating each cycle. The highest rates of atresia in follicular development occur around the time of antrum formation. It has been shown that the atretic process begins with cell death in the membrana granulosa initially by an apoptotic process [10]. Generally, apoptosis may be instigated intracellularly by cytotoxic stress, possibly due to free radicals or calcium influx [11] which cause mitochondrial changes that eventually also lead to caspase activation. Apoptosis can be initiated externally to the cell by the binding of 'death' ligands such as Fas ligand, tumour necrosis factor $\alpha$ (TNF $\alpha$ ) or TRAIL to specific receptors [12]. In follicular atresia it is unlikely that cell death occurs on a cell-by-cell basis because numerous pyknotic nuclei are observed during atresia [10]. Therefore it is probable that atresia is initiated by either the presence or absence of a particular external signal(s). TNF $\alpha$ can initiate apoptosis in granulosa cells $[13,14]$. The expression of TNF $\alpha$ receptors on granulosa and theca cells has been shown to be increased in atretic follicles when compared with healthy small or preovulatory follicles [15]. Studies on atretic follicles so far have shown that many of the genes/pathways involved are common to those stimulated by $\mathrm{TNF} \alpha$, as recently reviewed by Matsuda et al. [16].

Investigation of the effects of various agents on granulosa in vitro is dependent on the follicle stage at which the cells were isolated and the composition of the culture medium. It has been demonstrated that granulosa from small antral follicles are more responsive to FSH in serum-free culture and are capable of increasing oestradiol production over a six day period $[17,18]$. This is an important consideration for studying granulosa cells as they have a propensity to differentiate into granulosa-lutein cells in a process called luteinisation, if cultured in serum-supplemented medium [19]. Such cells are completely unresponsive to FSH. A previous study showed that TNF $\alpha$ was able to block the effects of FSH in serum-free culture of rat granulosa cells [20]. We were interested in the effect of FSH and TNF $\alpha$ on steroid production and global gene expression in bovine granulosa cells to help elucidate the mechanisms of action of these compounds at the transcriptional level. Interest in the action of pro-inflammatory signals like TNF $\alpha$ has been augmented by recent reports that ovarian granulosa cells of cattle and other species fulfil an innate immunity role, being capable of detecting and responding to bacterial pathogens [21]. We therefore cultured granulosa cells from small bovine follicles with or without FSH and TNF $\alpha$, alone and in combination, assayed steroid hormone production by immunoassay and conducted microarray analyses using Genechip bovine genome arrays.

\section{Results}

\section{Cell culture and hormone assays}

A dose response culture experiment was performed to determine the optimal concentrations of FSH and TNF $\alpha$ (Figure 1) to be used for the microarray experiments. On the basis of this experiment it was shown that oestradiol production was highest with a FSH dose of $0.33 \mathrm{ng} / \mathrm{ml}$, being significantly different from values observed at all other FSH concentrations in the absence of TNF $\alpha$. Ten $n g / m l$ of TNF $\alpha$ was sufficient to reduce this effect to the control level. Progesterone levels and viable cell number at the end of the culture period were not significantly $(P>0.05)$ affected by either FSH or TNF $\alpha$ treatment. On the basis of these results, $0.33 \mathrm{ng} / \mathrm{ml} \mathrm{FSH}$ and $10 \mathrm{ng} / \mathrm{ml}$ TNF $\alpha$ were selected for the culture of cells to be used for microarray analyses.

The results of the hormone secretion in the cultures of granulosa cells which were used for the microarray analyses are shown in Figure 2. FSH stimulation of the cultures produced a greater than 20 -fold induction $(P<0.05)$ of oestradiol secretion by the granulosa cells compared with the control cells (Figure 2). Conversely, TNF $\alpha$ treatment caused a $>65 \%$ reduction in the amount of oestradiol secretion under basal conditions $(P<0.05)$ and completely abolished the FSH-induced rise in oestradiol secretion $(P<0.05)$. Progesterone levels averaged approximately $200 \mathrm{ng} / \mathrm{ml}$ across all cultures, trending higher for the FSH-treated culture, but no significant differences were observed between the treatments (Figure 2). This confirms that the cultured granulosa cells maintained a hormone production profile characteristic of non-luteinised cells, and responded to FSH and TNF $\alpha$ as anticipated.

\section{Hierarchical clustering and principal component analyses (PCA)}

These analyses were performed on the sixteen microarrays, four from each treatment group, as presented in Figure 3 (PCA) and Additional file 1: Figure S1 (hierarchical clustering). These figures show that culture sample G9 from the 'control' group was quite different in signal intensity across most probe sets on the chip from the other controls, and in fact all other arrays. This result prompted us to consider this array as a statistical outlier, and it was excluded from further analyses. The other arrays formed two clusters on the basis of distribution of signal intensity, the 'TNF $\alpha$ and TNF $\alpha+$ FSH' groups (B in Figure 3), and the 'control and 

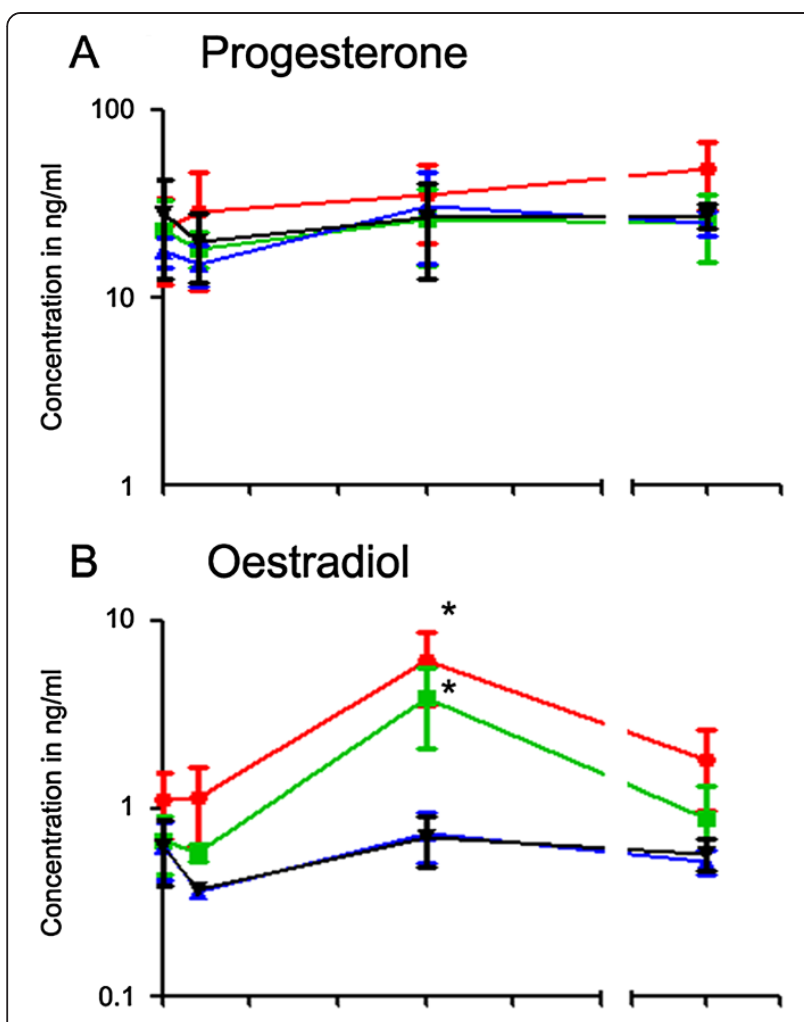

C Cell number

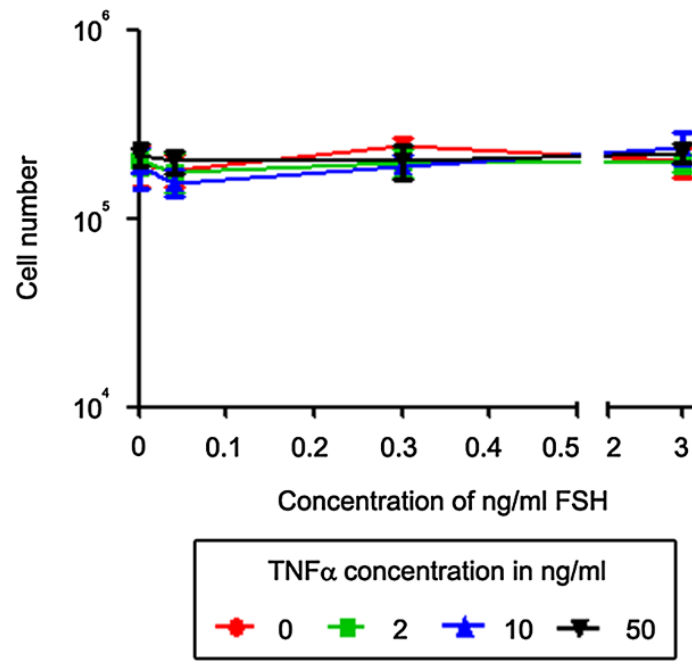

Figure 1 Dose response effects of FSH and TNFa. Oestradiol (A), progesterone (B) and cell numbers $(\mathbf{C})$ in cultured granulosa cells. The data represent the mean \pm SEM $(n=4)$. Cell numbers represent viable cells per $\mathrm{ml}$ at the end of culture. The axes are logarithmically scaled. *indicates significantly different from controls (two-way ANOVA with Fisher's LSD post hoc test, $P<0.05$ ).

FSH' groups (A in Figure 3). PCA was also conducted for the TNF $\alpha$ and the TNF + FSH-treated groups $(\mathrm{n}=8)$, and then for the control and the FSH-treated groups $(n=7)$. In both cases, for each comparison no differences were observed between the FSH treated and the non FSH-treated

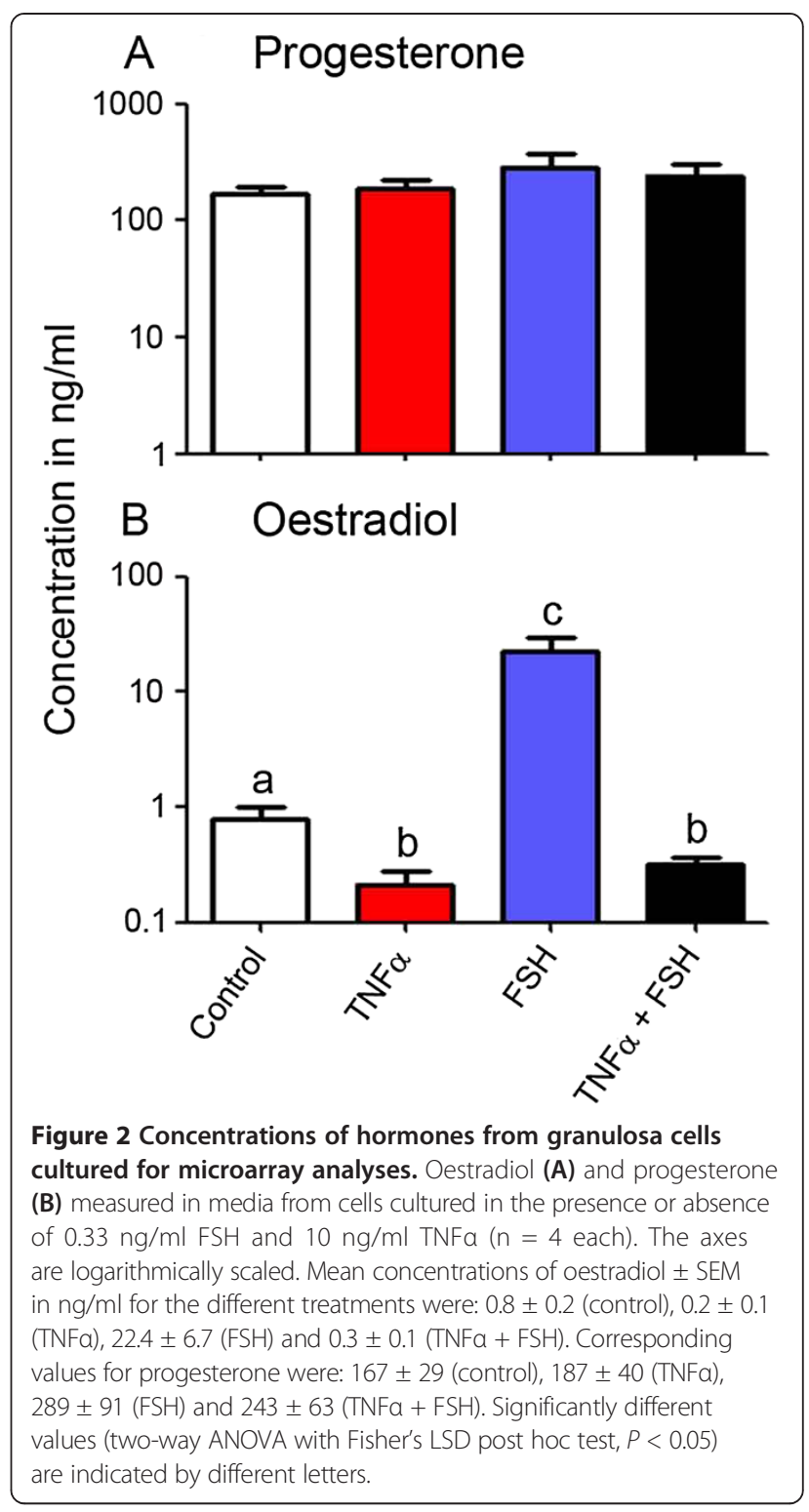

cells (Additional file 2: Figure S2). ANOVA demonstrated that no genes were different by more than 2-fold with an FDR of $P<0.05$. We can therefore assume that under our experimental culture conditions, FSH alone did not have a substantial effect on granulosa cell total gene expression, whereas TNFo had a major effect and actually overrode any effects of FSH when treated in combination.

\section{Quantitation of gene expression by RT-PCR}

Figure 4 shows the quantitative RT-PCR results for some of the genes which were significantly affected by FSH and/ or TNF $\alpha$ treatment of granulosa cells in culture: FSHR (A), the steroidogenic genes CYP19A1 (F), CYP11A1 (C), $H S D 3 B 1$ (D), HSD17B1 (E) and STAR (B), and other genes INHA (G), INHBA $(\mathrm{H})$ and FST (I). These genes are known to be active during antral follicular expansion when 


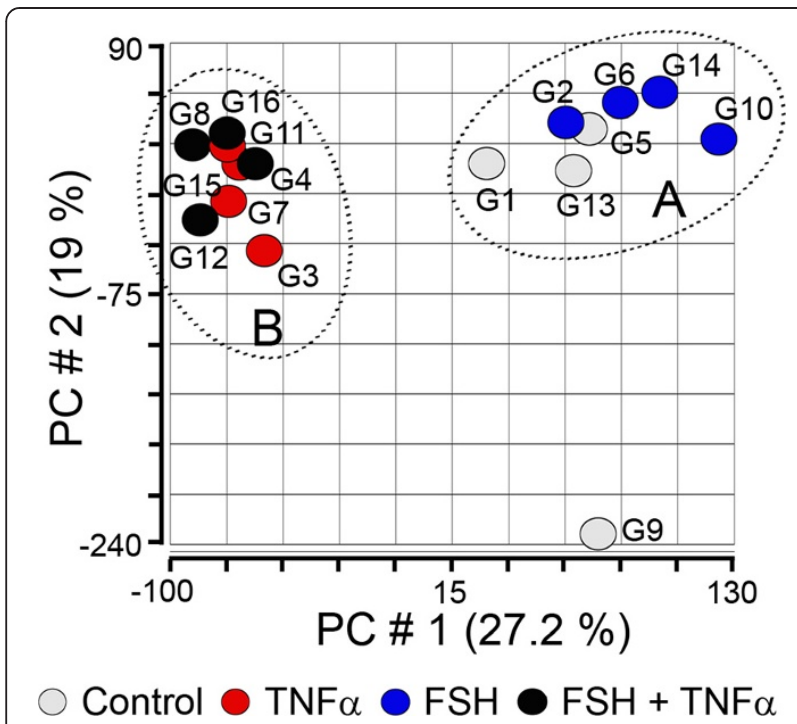

Figure 3 Unsupervised PCA of the granulosa cell arrays using Partek. The arrays are numbered ( $n=4$ per treatment) as follows: control granulosa (G1, G5, G9 and G13 in grey); FSH-treated (G2, G6, G10 and G14 in blue); TNFa-treated (G3, G7, G11 and G15 in red) and TNFa plus FSH-treated (G4, G8, G12, and G16 in black). The graph is a scatter plot of the values for the first $(X)$ and second $(Y)$ principal components based on the correlation matrix of the total normalised array intensity data. The groups of arrays (A) and (B), encircled by the dotted lines, represent related arrays based on patterns of total gene expression determined from the PCA. The G9 array had a considerably different pattern of gene expression from all the others and was therefore considered to be a statistical outlier and excluded from further analysis.

the granulosa cells are responsive to higher levels of FSH $[22,23]$. All genes except STAR, CYP11A1 and HSD3B1 were up regulated by FSH treatment alone. TNF $\alpha$, whether alone or in combination with FSH, decreased expression of the following genes below the level of the control: FSHR, STAR, $I N H A, I N H B$ and FST and the steroidogenic genes HSD17B1 and CYP19A1 to the level of the control. The decrease in CYP19A1, the gene encoding aromatase, the key enzyme of oestradiol synthesis, explains the observed decline in oestradiol production in the cultures under the influence of TNF $\alpha$ (Figure 2).

\section{Differential gene expression analyses}

Comparison of all treatments against the control group by ANOVA with a three-fold change and a statistical cut-off of $P<0.05$ produced a differentially-regulated list of 288 genes for the TNF $\alpha$-treated arrays compared with the controls, and 232 genes were common to both TNF $\alpha$ datasets and regulated in the same direction and to approximately the same degree (Additional file 3: Figure S3 and Additional file 4: Table S1). These numbers reflect the results of the unsupervised statistical analyses.

Although FSH was shown by qRT-PCR and microarray analyses to statistically alter a number of specific genes
(Figure 2), comparison of all treatments by ANOVA determined that no genes were differentially regulated by FSH treatment more than 2 fold with an FDR of $P<0.05$. Additionally the hierarchical clustering and PCA analyses (Figure 3 and Additional file 1: Figure S1) did not indicate any major effects of FSH. We therefore compared TNF \pm \pm FSH treated cultures $(n=8)$ with the control \pm FSH treated cultures $(n=7)$ and generated lists of differentially expressed genes as shown in Table 1. Lists of genes which were three-fold differentially expressed between these conditions are presented in Tables 2 and 3 and the full annotations of these genes are presented in Additional file 5: Table S2. This list was imported into Ingenuity Pathway Analysis (IPA) and Gene Ontology Enrichment Analysis Software Tool Kit (GOEAST) for functional pathway and network analyses.

IPA and GO enrichment analysis of TNFa regulated dataset Genes from the dataset that were differentially regulated > 3 fold and $P<0.05$ between TNF \pm FSH and control \pm FSH were mapped to canonical pathways in IPA and shown in Figure 5A. Many of the pathways were associated with immune cell function and inflammatory response pathways. Several of these pathways contain genes such as the nuclear factor-kappa- B complex (NF-kB) genes, NFKB1A and $N F K B 2$, interleukin receptor 1 and the cell survival gene PIK3R1. The GO enrichment analysis for this dataset (Figure 5B), also showed over-representation of processes such as antigen presentation, inflammation and stress response.

We also used IPA upstream regulator analysis to identify upstream transcriptional regulators. Upstream regulators were predicted using a Fisher's exact $t$-test to determine the probability that genes from the dataset correspond with targets which are known to be activated or inhibited by those molecules based on current knowledge in the Ingenuity database. Table 4 reveals a number of upstream regulators which were predicted to be influenced by TNF $\alpha$ treatment. It contained the inflammatory response mediators $I L 1 B$ and $I F 1 B$, and the matrix encoding gene $F N 1$. Interestingly, the interleukin receptor antagonist ILIRN was predicted to be down regulated, but it was shown to be up regulated according to the array intensity data.

The two highest scoring gene networks generated in IPA from our dataset for the effect of TNF $\alpha$ on the cultured granulosa are displayed in Figure 6. Network A shows an emphasis on innate immune response genes including several which are induced by interferon such as IFIT2, IFI44, IFIH1 and IFI27, which are all up regulated. Other genes in this network have some involvement with apoptotic signalling, namely RIPK4, FOXS1 and $B E X 2$. The molecule(s) forming most interactions in this network is the NF- $\mathrm{kB}$ complex, located within the nucleus. The other network (B) shows a focus around 


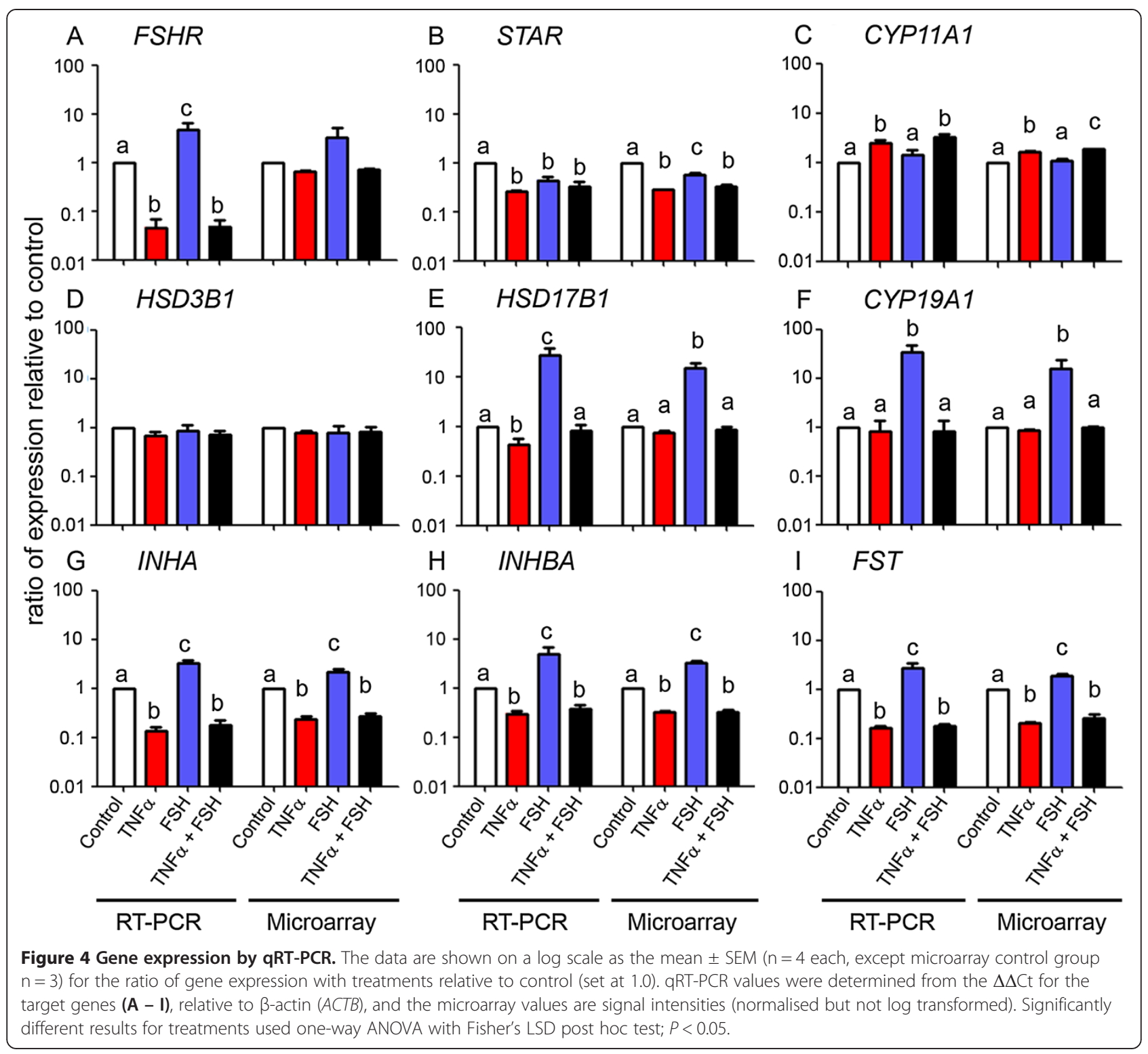

Table 1 The number of probe sets which were differentially regulated between control ( \pm FSH) and TNFa ( \pm FSH)-treated granulosa cell cultures

\begin{tabular}{llll}
\hline Fold change & Up regulated & Down regulated & Total \\
\hline$>2$ & 869 & 463 & 1332 \\
$>3$ & 400 & 127 & 527 \\
$>4$ & 234 & 161 & 295 \\
$>6$ & 107 & 12 & 119 \\
$>10$ & 40 & 0 & 40 \\
\hline
\end{tabular}

Numbers were determined by a one-way ANOVA with a FDR $P<0.05$ for multiple comparisons using Partek.
TGFB1 with interactions between other genes such as PDGF, COL16A1 and ADAMTSL4. There is also connectivity with the down-regulated genes INHA, INHBA and FST, which are all known to play a role in folliculogenesis as previously mentioned. Other genes which were highly activated due to TNF $\alpha$ treatment (Table 2 and Additional file 4: Table S1), included GPR77 and SLP1 (55-fold up regulated), PRKCB (20-fold), COL6A1 (13fold), KRT8 (10-fold) and HSD11B1 (6-fold). Amongst the down-regulated group of genes, CHST8 (8-fold) (Table 3 and Additional file 4: Table S1) may have a novel intrafollicular role.

\section{Discussion}

This study examined the effects of the treatment with FSH and TNFa, separately or combined, on granulosa 
Table 2 Genes which were $>3$-fold up regulated in TNFa ( \pm FSH)-treated granulosa cells compared with control ( \pm FSH) cells

\begin{tabular}{|c|c|c|c|c|c|}
\hline $\begin{array}{l}\text { Gene } \\
\text { symbol }\end{array}$ & $\begin{array}{c}\text { Fold change } \\
\text { (TNFa vs non TNFa treated) }\end{array}$ & $\begin{array}{c}\text { Gene } \\
\text { symbol }\end{array}$ & $\begin{array}{c}\text { Fold change } \\
\text { (TNFa vs non TNFa treated) }\end{array}$ & $\begin{array}{c}\text { Gene } \\
\text { symbol }\end{array}$ & $\begin{array}{c}\text { Fold change } \\
\text { (TNFa vs non TNFa treated) }\end{array}$ \\
\hline \multicolumn{6}{|c|}{ Cell death } \\
\hline TGM2 & 31 & XAF1 & 6.8 & IER3 & 3.6 \\
\hline CASP4 & 15.2 & $B C L 2 A 1$ & 5.3 & PYCARD1 & 3.3 \\
\hline$|F| 6$ & 9.2 & SAMD9 & 4.9 & TNFSF13B & 3.2 \\
\hline BEX2 & 8.6 & EGLN3 & 4.5 & RIPK4 & 3.1 \\
\hline BIRC3 & 8.6 & TRAF1 & 4.3 & & \\
\hline \multicolumn{6}{|c|}{ Cell morphology } \\
\hline KRT8 & 10 & ERP27 & 3.5 & NCK2 & 3.1 \\
\hline STMN2 & 7.7 & PDPN & 3.5 & TACC1 & 3.1 \\
\hline MAP2 & 4.7 & FMNL3 & 3.4 & GPHN & 3.0 \\
\hline DCLK1 & 4.5 & MSN & 3.4 & MFAP2 & 3.0 \\
\hline KRT18 & 4.2 & EMP3 & 3.3 & & \\
\hline \multicolumn{6}{|c|}{ Cytokines, hormones and receptors } \\
\hline GPR77 & 61.5 & CD83 & 6.3 & PLAUR & 3.8 \\
\hline CD44 & 21.5 & ROBO1 & 6.1 & HLA-DQA1 & 3.7 \\
\hline$|F| 44$ & 14.9 & IFIT2 & 6.0 & NTRK1 & 3.6 \\
\hline CD19 & 14.2 & $H L A-A$ & 5.9 & $\operatorname{IL36A}$ & 3.6 \\
\hline$|F| 16$ & 13.6 & HLA-DQA2 & 5.9 & EMR3 & 3.5 \\
\hline PTGER4 & 13.2 & $\operatorname{ILIRN}$ & 5.9 & TCRA & 3.5 \\
\hline CCL2 & 13.1 & GPR68 & 5.2 & TGFB1 & 3.5 \\
\hline SLCO4A1 & 12.3 & $H L A-D M B$ & 5.0 & GKN2 & 3.4 \\
\hline CD200 & 10.8 & ICAM1 & 4.7 & IFITM1 & 3.4 \\
\hline CXCL10 & 10.8 & $H L A-D R A$ & 4.6 & HLA-DRB3 & 3.3 \\
\hline CD40 & 10.1 & LYVE1 & 4.6 & FGF2 & 3.2 \\
\hline$|F| 27$ & 9.5 & $\| L 1 R 1$ & 4.5 & VIPR2 & 3.2 \\
\hline PLXND1 & 9.4 & NR4A2 & 4.3 & GPR56 & 3.1 \\
\hline$|F| H \mid$ & 7.1 & OLR1 & 4.0 & CD72 & 3.1 \\
\hline$J A G 1$ & 6.7 & $N R G 1$ & 3.9 & IGF2 & 3.1 \\
\hline CCL5 & 6.4 & PDGFB & 3.8 & & \\
\hline \multicolumn{6}{|c|}{ Extracellular matrix and synthesis } \\
\hline TNC & 52.3 & COL15A1 & 9.4 & FMOD & 4.0 \\
\hline COL6A1 & 14.5 & COL16A1 & 5.0 & $A G R N$ & 3.8 \\
\hline LOXL4 & 8.8 & COL5A3 & 4.6 & FN1 & 3.3 \\
\hline \multicolumn{6}{|c|}{ Intercellular and cell to matrix adhesion } \\
\hline BST2 & 6.4 & THBS3 & 3.6 & CEACAM8 & 3.2 \\
\hline VCAM1 & 5.3 & SPP1 & 3.6 & $\mathrm{CDH} 1$ & 3.1 \\
\hline CD82 & 4.8 & CD9 & 3.6 & & \\
\hline ITGA5 & 4.5 & NUAK2 & 3.4 & & \\
\hline \multicolumn{6}{|c|}{ Ion transport } \\
\hline KCNMA1 & 8.9 & FXYD3 & 3.9 & CLCA3P & 3.1 \\
\hline CACNAIG & 6.9 & GRIA3 & 3.7 & SLC25A12 & 3.0 \\
\hline CNGA3 & 4.3 & TPCN1 & 3.4 & & \\
\hline
\end{tabular}


Table 2 Genes which were $>3$-fold up regulated in TNFa ( \pm FSH)-treated granulosa cells compared with control ( \pm FSH) cells (Continued)

\begin{tabular}{|c|c|c|c|c|c|}
\hline \multicolumn{6}{|c|}{ Proteolysis and inhibition } \\
\hline SLPI & 58.6 & MMP2 & 5.0 & CTSH & 3.5 \\
\hline UBD & 17.1 & PSMB10 & 3.9 & TFPI2 & 3.5 \\
\hline SERPINB2 & 14.9 & PSMB8 & 3.8 & TRIM21 & 3.2 \\
\hline SERPINA5 & 12.5 & ADAMTSL4 & 3.8 & UBA7 & 3.2 \\
\hline ISG15 & 10.8 & ERAP2 & 3.8 & PRSS2 & 3.1 \\
\hline ADAM23 & 8.3 & USP18 & 3.7 & CFD & 3.1 \\
\hline$A 2 M$ & 5.6 & TIMP3 & 3.7 & CSTB & 3.1 \\
\hline PSMB9 & 5.1 & C1S & 3.6 & & \\
\hline \multicolumn{6}{|c|}{ Transcriptional regulation } \\
\hline GFI1 & 14.1 & IRFI & 4.7 & NFKB2 & 3.7 \\
\hline NFKBIA & 9.8 & HEYL & 4.7 & NFKBIZ & 3.6 \\
\hline FOXA3 & 9.0 & HES4 & 4.6 & H19 & 3.5 \\
\hline MYB & 8.4 & IRF8 & 4.2 & SNAl1 & 3.4 \\
\hline MIR147 & 5.3 & LRRFIP1 & 4.0 & NOSTRIN & 3.4 \\
\hline TBX3 & 5.2 & NUPR1 & 4.0 & DTX1 & 3.3 \\
\hline BHLHE4O & 4.8 & RBPMS & 3.9 & FOXS1 & 3.3 \\
\hline TCF7 & 4.8 & IKZF3 & 3.8 & STAT5A & 3.1 \\
\hline \multicolumn{6}{|c|}{ Transport } \\
\hline RTP4 & 14.5 & $R A B 3 / P$ & 3.8 & SLC37A1 & 3.5 \\
\hline$A B C C 3$ & 8.0 & ANKH & 3.7 & SLCO2AI & 3.4 \\
\hline TF & 4.1 & TAP1 & 3.5 & SYNGR1 & 3.1 \\
\hline \multicolumn{6}{|c|}{ Other enzymes } \\
\hline PRKCB & 19.3 & PNPO & 5.0 & TPST2 & 3.9 \\
\hline PTGIS & 12.2 & PIK3CD & 5.0 & PRKCQ & 3.9 \\
\hline ALDH1A3 & 11.7 & GBP4 & 4.8 & CA5B & 3.8 \\
\hline OAS2 & 10.5 & MIOX & 4.7 & PARP14 & 3.7 \\
\hline PON3 & 9.3 & $A D C Y 2$ & 4.7 & PARP12 & 3.7 \\
\hline$D D C$ & 8.7 & ADH6 & 4.5 & LRAT & 3.5 \\
\hline IDO1 & 7.7 & UMPS & 4.4 & $C K B$ & 3.4 \\
\hline MX2 & 7.5 & CA2 & 4.4 & CAMK1D & 3.3 \\
\hline HSD11B1 & 7.0 & RSAD2 & 4.3 & $F B P 1$ & 3.3 \\
\hline MX1 & 6.6 & PPP2R3C & 4.3 & PARPQ & 3.2 \\
\hline OAS1 & 5.5 & BCAT2 & 4.3 & PNKD & 3.2 \\
\hline ABHD3 & 5.2 & SQRDL & 4.1 & CAB & 3.1 \\
\hline GLDC & 5.2 & ISG20 & 4.0 & & \\
\hline$X D H$ & 5.2 & $A P O B E C 3 B$ & 3.9 & & \\
\hline \multicolumn{6}{|c|}{ Other signalling } \\
\hline ENTPD3 & 17.7 & DNER & 5.8 & ARHGAP24 & 4.8 \\
\hline ARHGEF5 & 13.6 & RASAL1 & 5.2 & DDX58 & 3.3 \\
\hline NFKB1A & 9.8 & TNIP1 & 5.5 & WNT11 & 3.2 \\
\hline ARHGAP29 & 8.7 & ARHGEF11 & 5.1 & $N K G 7$ & 3.4 \\
\hline ANXABL1 & 8.0 & ARRDC2 & 4.3 & CDC42EP1 & 3.3 \\
\hline SLAMF8 & 7.4 & RGS16 & 4.1 & PDE4B & 3.5 \\
\hline
\end{tabular}


Table 2 Genes which were $>3$-fold up regulated in TNFa ( \pm FSH)-treated granulosa cells compared with control ( \pm FSH) cells (Continued)

\begin{tabular}{llclcc}
\hline TAC3 & 8.7 & SHISA3 & 4.1 & IFI30 & 3.2 \\
GAL & 4.6 & GBP5 & 4.0 & RNF128 & 3.0 \\
DAPP1 & 5.0 & ARHGDIB & 3.8 & & \\
& & & & \\
TREM1 & Other & & DPY19L1 & 3.6 \\
PLAC8 & 11.2 & TMEM45B & 4.6 & NELL2 & 3.6 \\
PARM1 & 7.7 & MS4A8B & 4.6 & TMEM140 & 3.4 \\
EPB41L3 & 6.5 & SAA3 & 4.6 & CCDC85C & 3.4 \\
FATE1 & 6.3 & SELENBP1 & 4.4 & OAF & 3.2 \\
TRIM47 & CRYBB1 & 4.4 & TMED6 & 3.2 \\
SPARCL1 & HPCAL1 & 4.2 & ABTB2 & 3.2 \\
NUCB2 & 5.4 & 4.0 & CRIP2 & 3.2 \\
PDLIM4 & 5.4 & UNC13D & 3.9 & CSRP2 & 3.1 \\
\hline
\end{tabular}

Genes are categorised by function and listed in descending order of fold change in each category. The association of genes with functional terms in this table was determined manually for each gene based on information obtained through the Entrez Gene database of NCBI. The level of fold change and statistical significance ( $\geq 3$-fold change, $P<0.05$ ) were determined using the step up Benjamini-Hochberg post-hoc test for multiple corrections following one way ANOVA.

cells cultured under serum-free conditions and maintained in a non-luteinised state. The effect of FSH alone at $0.33 \mathrm{ng} / \mathrm{ml}$ paralleled the result of a previous study by Glister et al. [17], with similar increases in oestradiol production and expression of follistatin and inhibin A confirming the robustness of this physiologically relevant in vitro model used in the current experiments. Moreover, our qRT-PCR findings confirmed the ability of FSH to up regulate expression of its cognate receptor (FSHR) as reported previously [23,24] although a statistically significant difference was not detected by microarray analysis. With the exception of FSHR, there was excellent agreement between microarray and qRT-PCR data with respect to treatment effects on the other eight transcripts used for validation purposes. The ability of TNF $\alpha$ to suppress the production of oestradiol in our experiment was also expected from results of previous studies in serum-free [13] and serum-supplemented [15] culture systems.

The unsupervised array analyses and the numbers of genes differentially regulated, show surprisingly perhaps, that in our experiment FSH alone had a minor effect on total gene expression, compared with TNF $\alpha$, where many genes were differentially regulated. The effects of FSH were limited to stimulation of energy metabolism and steroidogenesis in overall terms, in comparison with TNF $\alpha$ which mainly influenced inflammatory pathways and molecules. Clearly the main specific effect of FSH treatment was to stimulate oestradiol production by up regulation of aromatase expression (CYP19A1). The production of oestradiol and the concomitant activation of the folliculogenesis regulating genes for inhibin $\mathrm{A}$ and follistatin occur through recognised FSH cascade signalling involving cyclic AMP and protein kinase A [24]. The relatively low dose of FSH $(0.33 \mathrm{ng} / \mathrm{ml})$ used to treat the cells in our microarray experiment was selected as being optimal for promoting oestradiol secretion and was insufficient to induce an increase in progesterone synthesis or proliferation of the granulosa cells in culture. However, there was transcriptional activation of the cyclin B1 and B2 genes, which indicates an increase in mitotic activity, although a net increase in cell number was not observed under the culture conditions used. The endocrine functions of granulosa cells appeared to be down regulated upon TNF $\alpha$ treatments with reductions in FST (6.2 fold), INHA (5.8 fold), INBA (5.8 fold), $A M H$ (3.4 fold).

CHST8 was also down regulated in the TNF $\alpha-$ responsive datasets. The encoded enzyme is a sulphur transferase that sulphates $N$-acetylgalactosamine $\beta 1,4$ linked with $N$-acetylglucosamine (LacdiNAc) moieties on certain glycoproteins prior to secretion [25]. Sulphation of these structures can modulate the activity of these molecules by affecting the kinetics of binding [26] and increases their rate of clearance from the body [27]. Glycodelin, an immune mediator, is produced by the granulosa cells at antral stages and possesses these LacdiNAc moieties. Glycodelin is taken up by the cumulus cells, where it is deglycosylated, loses immunosuppressive function and acquires properties beneficial to the fertilisation process [28]. It may be possible that sulphation may also play a role in determining the activity of glycodelin, but confirmation of this would require further investigation. 
Table 3 Genes which are $>3$-fold down regulated in TNFa ( \pm FSH)-treated granulosa cells compared with control ( \pm FSH) cells

\begin{tabular}{|c|c|c|c|c|c|}
\hline $\begin{array}{l}\text { Gene } \\
\text { symbol }\end{array}$ & $\begin{array}{c}\text { Fold change } \\
\text { (TNFa vs non TNFa treated) }\end{array}$ & $\begin{array}{c}\text { Gene } \\
\text { symbol }\end{array}$ & $\begin{array}{c}\text { Fold change } \\
\text { (TNFa vs non TNFa treated) }\end{array}$ & $\begin{array}{l}\text { Gene } \\
\text { symbol }\end{array}$ & $\begin{array}{c}\text { Fold change } \\
\text { (TNFa vs non TNFa treated) }\end{array}$ \\
\hline \multicolumn{6}{|c|}{ Apoptosis } \\
\hline TRIB2 & 5.7 & & & & \\
\hline \multicolumn{6}{|c|}{ Cell morphology } \\
\hline DACT1 & 4.1 & ACTG2 & 3.3 & MYO1B & 3.1 \\
\hline \multicolumn{6}{|c|}{ Cytokines, hormones and receptors } \\
\hline $\mathrm{ROBO} 2$ & 7.9 & HEG1 & 5 & PTN & 3.5 \\
\hline EFNA5 & 7.3 & PLXNC1 & 4.4 & $A M H$ & 3.4 \\
\hline FST & 6.2 & PPARG & 4.2 & NR5A2 & 3.1 \\
\hline INHA & 5.8 & ANGPT2 & 3.8 & KIT & 3 \\
\hline INHBA & 5.8 & CD36 & 3.6 & & \\
\hline NMB & 5.5 & EPHA7 & 3.6 & & \\
\hline \multicolumn{6}{|c|}{ Extracellular matrix and synthesis } \\
\hline SPOCK2 & 5.0 & FBLN5 & 4.8 & EFEMP1 & 3.3 \\
\hline$S R G N$ & 5.5 & & & & \\
\hline \multicolumn{6}{|c|}{ Intercellular and cell to matrix adhesion } \\
\hline CYR61 & 5 & CAV1 & 4.1 & CTNNAL1 & 3.3 \\
\hline TSPAN5 & 4.9 & TNFAIP6 & 3.5 & CLDND1 & 3.3 \\
\hline NPNT & 4.6 & SMOC2 & 3.4 & & \\
\hline \multicolumn{6}{|c|}{ lon transport } \\
\hline KCNN2 & 3.6 & ATP4B & 3.1 & & \\
\hline \multicolumn{6}{|c|}{ Proteolysis and inhibition } \\
\hline TLL2 & 4.8 & PRSS35 & 3.4 & SERPINE2 & 3.0 \\
\hline \multicolumn{6}{|c|}{ Transcription regulation } \\
\hline TOX & 4.1 & & & & \\
\hline \multicolumn{6}{|c|}{ Transport } \\
\hline MAL2 & 4.0 & $S L C 2 A 3$ & 3.7 & NPC1 & 3.0 \\
\hline \multicolumn{6}{|c|}{ Other enzymes } \\
\hline CHST8 & 8.4 & DDAH1 & 4.4 & PLA2G7 & 3.5 \\
\hline VNN1 & 6.4 & HPSE & 4.1 & GCLC & 3.4 \\
\hline STC1 & 5.8 & MVK & 3.7 & TRIM2 & 3.2 \\
\hline PPAP2B & 5.5 & PDK4 & 3.6 & & \\
\hline HSD17B1 & 4.8 & GYLTL1B & 3.6 & & \\
\hline PTGS2 & 4.6 & & & & \\
\hline \multicolumn{6}{|c|}{ Other signalling } \\
\hline TPD52L1 & 7.3 & $D A B 2$ & 3.4 & CCND2 & 3.1 \\
\hline RGS2 & 4.6 & FGD5 & 3.2 & SMAD2 & 3.1 \\
\hline SORBS2 & 4.4 & RASLI1B & 3.2 & & \\
\hline$R G M B$ & 3.8 & NTS & 3.2 & & \\
\hline \multicolumn{6}{|c|}{ Other } \\
\hline ZNF608 & 4.6 & EEPD1 & 4.4 & CAPRIN2 & 3.5 \\
\hline SUSD4 & 4.5 & LINGO2 & 3.7 & LGALS3 & 3.1 \\
\hline
\end{tabular}

The level of fold change and statistical significance ( $\geq 3$-fold, $P<0.05$ ) was determined by one-way ANOVA with post-hoc Benjamini-Hochberg testing for multiple corrections. The association of genes with functional terms in this table was determined manually for each gene based on information obtained through the Entrez Gene database of NCBI. Genes are listed in descending order of fold change in each category. 


\section{A}

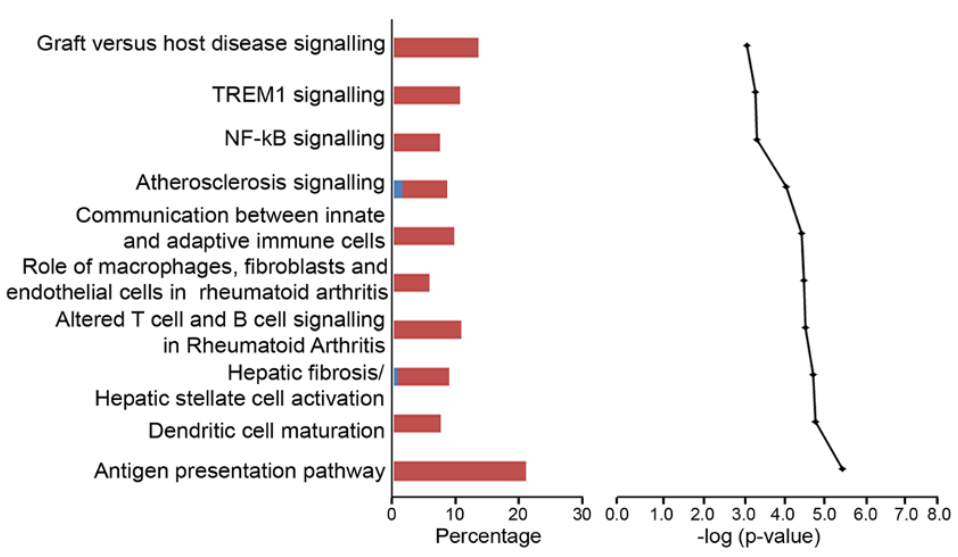

Downregulated in TNF $\alpha+/$-FSH versus FSH-treated and control groups

Upregulated in $\mathrm{TNF} \alpha+/-\mathrm{FSH}$ versus $\mathrm{FSH}$-treated and control groups

\section{B}

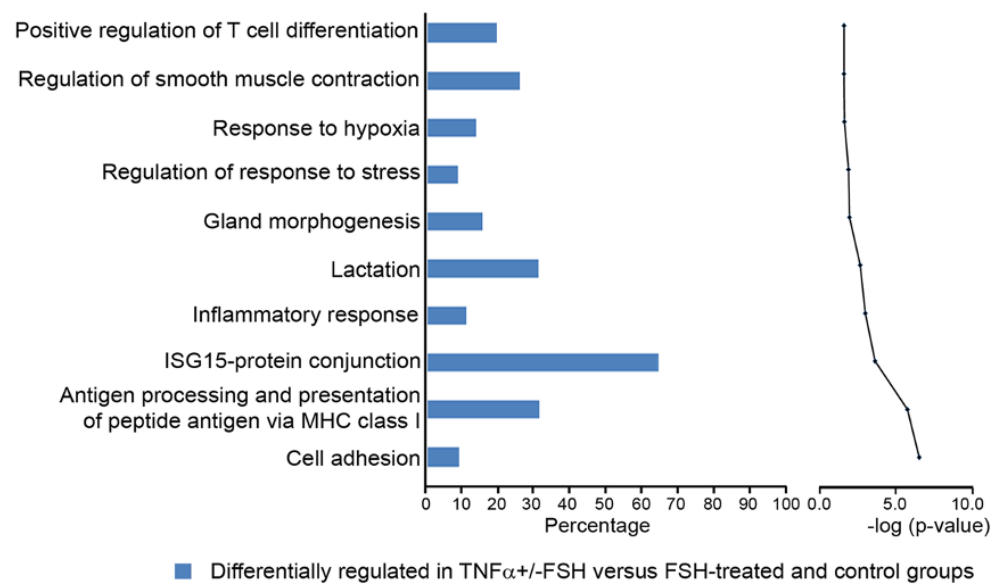

Figure 5 Top ten canonical pathways and highly enriched GO terms. Determined for genes differentially regulated between control ( \pm FSH) and TNFa ( \pm FSH)-treated granulosa cells ( $n=527$ probe sets, 379 genes mapped to IPA). In (A) the bar charts represent the percentage of genes from the dataset that map to each canonical pathway in IPA (up regulated in red and down regulated in blue for TNFa ( \pm FSH)-treated granulosa cells). The line chart ranks the pathways derived from the highest to lowest degree (bottom to top) of association based on the value of a Benjamini-Hochberg test for multiple corrections. In (B) the bar charts represent the percentage of differentially-regulated genes between control $( \pm$ FSH) and TNFa $( \pm$ FSH)-treated granulosa cells. Only the most specific subcategories of GO terms under biological process which were considered significant by the Benjamini-Yuketeli test $(P<0.05)$ were ranked.

It is known that TNF $\alpha$ exerts its apoptotic effects through the Type I receptor (TNFR1), whereas other pro-inflammatory actions on growth and differentiation are mediated via the Type II receptor (TNFRII) as previously reviewed by Matsuda et al. [16]. Since we did not observe any effect on viable cell number after 4 days exposure to TNF $\alpha$, this might suggest that TNF $\alpha$ did not induce apoptosis in the granulosa cells and may act predominantly via TNFRII in our culture system to activate a pro-inflammatory cascade that modifies other aspects of cell function including matrix remodelling and up regulation of antigen presentation molecules. Many of the genes whose expression in granulosa cells was up regulated by TNFa are often associated with innate immune responses. This reinforces recent evidence that granulosa cells can act as immune sensors and play an active role in initiating protective inflammatory responses to bacterial pathogens, recognised via interaction of pathogenassociated molecular patterns (PAMPs) such as lipopolysaccharide, with toll-like receptor 4 (TLR4) on the cell surface $[21,29,30]$. Indeed, bovine granulosa cells were recently shown to express a full complement of TLRs. Moreover, functional inflammatory responses to PAMPs interacting with TLR2 and TLR4 were demonstrated [21].

The genes influenced by TNF $\alpha$ treatment were generally associated with endocrine function, apoptosis, inflammation, and degradation as were expected from previous studies. In our culture system, TNF $\alpha$ alone did not cause any net loss of cells. Some pro-apoptotic (XAF1, CASP4), but more anti-apoptotic genes (TGM2, BCL2A1, BIRC3, 
Table 4 Upstream regulators determined by IPA to be activated or inhibited by TNFa ( \pm FSH) treatment of cultured granulosa cells ${ }^{\dagger}$

\begin{tabular}{|c|c|c|c|c|}
\hline Gene symbol or molecule & Full gene name & Actual fold change & Activation z-score & $P$ value of overlap \\
\hline TNF & Tumour necrosis factor & & 6.52 & $7.03 \mathrm{E}-39$ \\
\hline IFNG & Interferon gamma & & 6.75 & $6.34 \mathrm{E}-35$ \\
\hline IL1B & Interleukin 1, beta & & 4.76 & $9.88 \mathrm{E}-28$ \\
\hline Tretinoin & All-trans retinoic acid & & 4.12 & $7.15 \mathrm{E}-25$ \\
\hline IFNB1 & Interferon beta 1 & & 3.66 & $8.03 \mathrm{E}-20$ \\
\hline OSM & Oncostatin M & & 4.29 & $5.93 \mathrm{E}-16$ \\
\hline CD40 & CD40 molecule, TNF receptor superfamily member 5 & 10.1 & 3.25 & $2.36 \mathrm{E}-13$ \\
\hline TGM2 & Transglutaminase 2 & 31.0 & 3.34 & $1.05 \mathrm{E}-12$ \\
\hline FN1 & Fibronectin 1 & 3.3 & 3.05 & $7.85 \mathrm{E}-11$ \\
\hline ESR1 & Estrogen Receptor 1 & & 3.07 & $1.99 \mathrm{E}-07$ \\
\hline $\mathrm{HTT}$ & Huntingtin & & 3.32 & $8.34 \mathrm{E}-07$ \\
\hline IL1RN & Interleukin 1 receptor antagonist & 5.9 & -3.60 & $8.11 \mathrm{E}-19$ \\
\hline
\end{tabular}

${ }^{\dagger}$ Genes $>3$-fold differentially regulated between TNFa ( \pm FSH) and control $( \pm$ FSH) were used for this analysis.

The $P$ value of overlap is the calculated statistical significance of overlap between genes from the dataset and genes that are known to be regulated by the upstream regulator using Fisher's exact test.

The bias-corrected z-score is used to infer the activation states of transcriptional regulators. It is calculated from the proportions of genes which are differentially regulated in an expected direction based on the known interactions between the regulator and the genes present in the Ingenuity database. Those genes with a $z$-score greater or less than two are considered to be either activated or inhibited respectively.

TNIP1), in fact, appeared to be stimulated by TNF $\alpha$. It is likely that the genes which act to block the apoptotic process are responding as a cellular survival mechanism, although some may be directly activated via the TNFa signalling pathway. The blocking effect of TNF $\alpha$ on FSHinduced oestradiol production has been shown previously to be suppressed by treatment with peroxisome proliferator-activated receptor (PPAR) $\gamma$ ligands [31], and in this study PPARG expression was inhibited by TNFa, indicating that this lipid metabolism pathway was also involved. HSD11B1 encodes a key enzyme in glucocorticoid metabolism and has been previously shown to be activated by TNF $\alpha$ via the regulatory gene $C E B P B$ in cultured cells [32].

The genes identified as being most highly up regulated by TNF $\alpha$ include TGM2 (31-fold), GPR77 (62-fold), SLPI (59-fold) and TNC (52-fold), none of which have previously been noted in granulosa cells. TGM2 catalyses the cross-linking of proteins and the conjugation of polyamines to proteins. It is also implicated as a positive

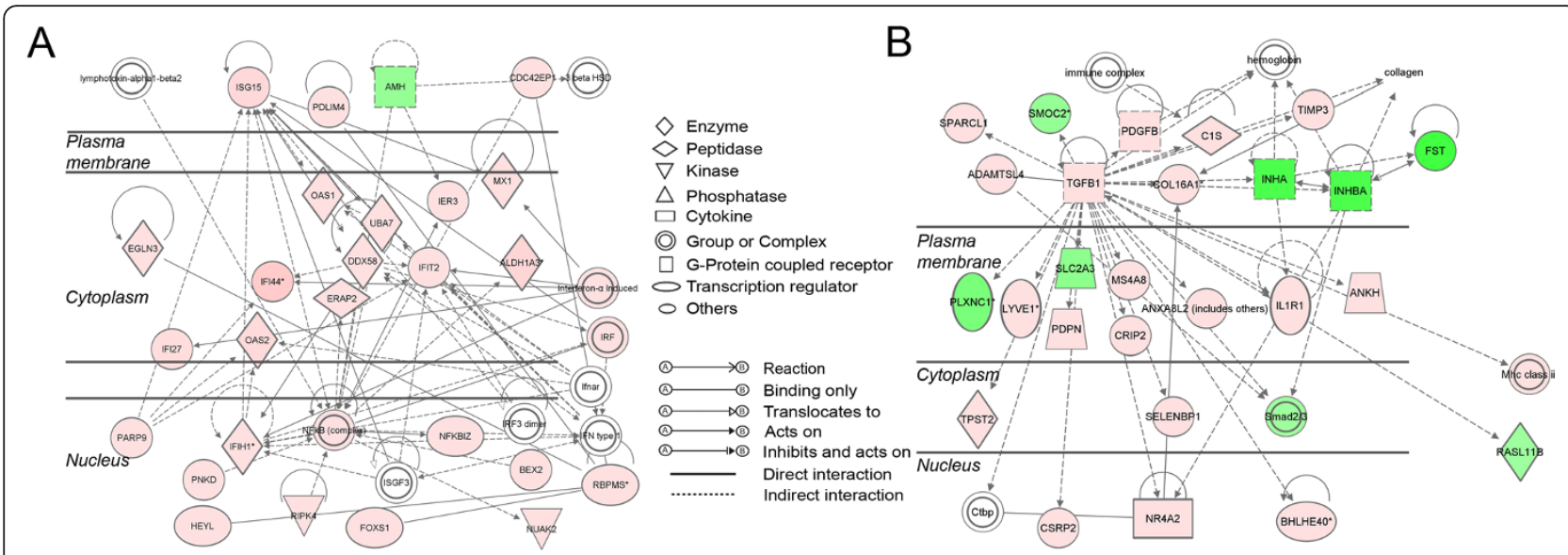

Figure 6 The top two networks (A and B) determined in IPA. Genes were differentially regulated between TNFa ( \pm FSH)-treated and control $( \pm$ FSH)-treated granulosa cells ( $n=379$ genes mapped to IPA). The networks were generated by a modified triangle connectivity algorithm based on the proportion of known interactions between molecules in this dataset (focus molecules) and others in the IPA database. Both networks were scored at 44 (-log of $P$ value of Fisher's exact $t$-test), and mapped 26 genes each from the differentially expressed dataset. Interactions between molecules are shown as explained in the legend, with focus molecule symbols highlighted in colour, based on up (red) or down (green) regulation and increasing colour intensity with degree of fold change. 
regulator of the inflammatory response, NF- $\mathrm{kB}$ signalling and cell adhesion [33]. GPR77 (62-fold) is one of several receptors for the $\mathrm{C} 5 \mathrm{a}$ molecule, a major chemotactic and pro-inflammatory product of the complement cascade activated during the innate immune response [34]. SLPI (59fold) was first characterised as a protease inhibitor but is now recognised as having additional properties including antimicrobial and immunomodulatory activities associated with the innate immune response. SLPI is up regulated by pro-inflammatory mediators and appears to have a tissue protective role [35,36]. TNC (52-fold) is an extracellular matrix molecule that is highly expressed during embryonic development but is normally present in low amounts in adult tissues. However, TNC expression is up regulated in pathological situations involving tissue injury, wound healing, inflammation and cancer. TNC influences cell migration, proliferation and cell signalling pathways through a variety of mechanisms including induction of proinflammatory cytokines [37].

\section{Conclusions}

In vitro, the transcriptome of granulosa cells responded minimally to FSH compared with the response to TNF $\alpha$. The response to TNF $\alpha$ indicated a reduction in endocrine function and an active process akin to tissue repair and remodelling as would occur upon atresia. Additionally there was an inflammatory response to TNF $\alpha$ that displays many features normally associated with immune cells.

\section{Methods}

Bovine ovaries and primary culture of granulosa cells

Bovine granulosa cells were isolated from adult bovine ovaries obtained from a local abattoir as described previously $[17,18,38]$. Contamination with theca cells was judged to be $<1 \%$ based on comparison of the relative expression of CYP17A1 and LHCGR in freshly isolated granulosa cells and theca cells as determined by qRTPCR (data not shown). For each experiment cells were pooled from approximately 50 individual $4-6 \mathrm{~mm}$ follicles and seeded at $5 \times 10^{5}$ viable cells/ml into 24-well (microarray) or 75,000 cells $/ 0.2 \mathrm{ml}$ into 96 well plates (dose response) with four replicate wells per treatment. Cells were cultured for six days under defined serumfree conditions. The culture medium used consisted of McCoy's 5A modified medium supplemented with 1\% $(\mathrm{v} / \mathrm{v})$ antibiotic-antimycotic solution, $10 \mathrm{ng} / \mathrm{ml}$ bovine insulin, $2 \mathrm{mM}$ L-glutamine, $10 \mathrm{mM}$ HEPES, $5 \mu \mathrm{g} / \mathrm{ml}$ apotransferrin, $5 \mathrm{ng} / \mathrm{ml}$ sodium selenite and $0.1 \%(\mathrm{w} / \mathrm{v})$ BSA (all purchased from Sigma UK Ltd, Poole, Dorset, UK). The culture medium was supplemented with $10^{-7} \mathrm{~mol} / \mathrm{l}$ androstenedione (Sigma UK Ltd, Poole, Dorset, UK) as a substrate for cytochrome P450 aromatase. Media were removed after $48 \mathrm{~h}$ and $96 \mathrm{~h}$ and replaced with fresh media containing treatments described below. Conditioned media were retained for hormone assays, and at the end of culture either viable cell number was determined (dose-response experiment) by neutral red uptake assay [17] or cell lysates were prepared (microarray experiment) using the lysis buffer component of the RiboPure RNA isolation kit (Ambion/ Life Technologies Ltd., Paisley, UK). Pooled lysates from replicate wells were stored at -80C until total RNA isolation. Each experiment was repeated four times using cells harvested from independent batches of ovaries.

\section{Treatments}

Highly purified ovine FSH (NIADDK oFSH-19SIAPP) was supplied by NHPP, Torrance, CA, USA. Recombinant human TNFo was purchased from Sigma Aldrich, St Louis, MO, USA (Cat\# T6674 with a stated endotoxin level $<1$ ng/ug). Treatments were dissolved in Hank's balanced-salt solution containing $0.1 \%(\mathrm{w} / \mathrm{v})$ BSA and stock solutions sterilized using $0.2 \mu \mathrm{m}$ membrane filters before dilution in the culture medium. These treatments were applied on days 3 to 6 of culture for both the microarray and dose response experiments under the conditions specified above.

\section{Steroid immunoassays}

The concentrations of oestradiol in conditioned media were determined by radioimmunoassay [39]. The detection limit of the assay was $2 \mathrm{pg} / \mathrm{ml}$ and mean intra- and inter-assay CVs were 6\% and 9\% respectively. Concentrations of progesterone in conditioned media were determined by competitive ELISA [40]. The detection limit was $0.1 \mathrm{ng} / \mathrm{ml}$ and mean intra- and inter-assay CVs were $8 \%$ and $11 \%$ respectively.

\section{Total RNA isolation, microarray analysis and quantitative RT-PCR}

Total RNA was isolated from cultured cells for microarray analysis and for validation using qRT-PCR. RNA was isolated using the RiboPure ${ }^{\text {Tw }}$ RNA isolation kit (Ambion) according to the manufacturer's instructions. RNA yield and quality were evaluated by spectrophotometry at 260/ $280 \mathrm{~nm}$ and agarose gel electrophoresis before submitting samples $(\mathrm{n}=16)$ to an accredited Affymetrix service provider (Almac Diagnostics Ltd, Craigavon, Northern Ireland) for microarray analysis. For qRT-PCR analysis, first strand cDNA was synthesized from $1 \mu \mathrm{g}$ of total RNA using the Reverse-i $\mathrm{T}^{\mathrm{Tx}}$ reverse transcription kit (used according to manufacturer's protocol; Abgene, Epsom, Surrey, UK) in a $20 \mu \mathrm{l}$ reaction primed with random hexamers. Primers (see Table 5) were designed to amplify target sequences using Primer Express software (Applied Biosystems/ Life Technologies Ltd) or the online Primer Design Tool (NCBI/Primer-BLAST). In primer validation 
Table 5 List of primers used for qRT-PCR

\begin{tabular}{|c|c|c|c|c|}
\hline Target & Genbank accession number & Forward primer $5^{\prime}$ to $3^{\prime}$ & Reverse primer $5^{\prime}$ to $3^{\prime}$ & Amplicon size (bp) \\
\hline FSHR & NM_174061 & GCCAGCCTCACCTACCCCAGC & AATTGGATGAAGGTCAGAGGTTTGCC & 75 \\
\hline STAR & NM_174189 & TIIITCCTGGGTCCTGACAGCGTC & ACAACCTGATCCTTGGGTTCTGCACC & 103 \\
\hline CYP11A1 & NM_176644 & CAGTGTCCCTCTGCTCAACGTCC & TTATTGAAAATTGTGTCCCATGCGG & 99 \\
\hline HSD3B1 & NM_174343 & GCCACCTAGTGACTCTITCCAACAGCG & TGGTTTCTGCTTGGCTTCCTCCC & 111 \\
\hline HSD17B1 & NM_001102365 & CGCATATTGGTGACCGGGAGCATA & AATCGCCAGACTCTCGCACAAACC & 108 \\
\hline CYP19A1 & NM_174305 & CGCCACTGAGTTGATTITTGCTGAGA & TAAGGCTITGCGCATGACCAGGTC & 301 \\
\hline ACTB & NM_173979 & ATCACCATCGGCAATGAGCGGTTC & CGGATGTCGACGTCACACTTCATGA & 128 \\
\hline INHBA & NM_174363 & GAAGAGACCCGATGTCACCCAGC & TGTCGTCCTCTATCTCCACGTACCCG & 113 \\
\hline INHA & NM_174094 & GAGCCCGAGGACCAAGATGTCTCC & CCTCAGCCTCTCCAGCATCTGGC & 91 \\
\hline FST & NM_175801 & TGAGCAAGGAGGAGTGTTGCAGCA & CATCTGGCCTTGAGGAGTGCACATTC & 301 \\
\hline
\end{tabular}

experiments, dissociation curve analysis and agarose gel electrophoresis were used to verify that each primer pair generated a single product of the predicted size. cDNA template log-dilution curves were used to demonstrate satisfactory PCR efficiency (> 85\%) and linearity. PCR assays were carried out in a volume of $14 \mu \mathrm{l}$, comprising $5 \mu \mathrm{l}$ cDNA template (1/50 dilution), $1 \mu \mathrm{l}$ each forward and reverse primers (final concentration $0.4 \mu \mathrm{M}$ ) and $7 \mu \mathrm{l}$ QuantiTect SYBR Green qPCR 2x Master Mix (Qiagen Ltd., Crawley, west Sussex, UK). Samples were processed on a StepOne ${ }^{\mathrm{TM}}$ Plus real-time PCR instrument (Applied Biosystems/ Life Technologies Ltd.) with the following thermal cycling conditions: $15 \mathrm{~min}$ at $95^{\circ} \mathrm{C}$ (one cycle) followed by $15 \mathrm{~s}$ at $95^{\circ} \mathrm{C}$ and $1 \mathrm{~min}$ at $60^{\circ} \mathrm{C}$ ( 40 cycles).

For qRT-PCR analyses, the $\Delta \Delta \mathrm{Ct}$ method [41] was used for comparison of the relative abundance of each mRNA transcript. $\mathrm{Ct}$ values for each transcript in a given sample were first normalised to the $\beta$-actin $C t$ value (which was uniform across all experimental groups: ANOVA $P>0.1$ ). Resultant $\Delta C t$ values for individual replicates within each treatment group were then normalised to the average $\Delta \mathrm{Ct}$ value of the respective vehicle-treated control group. These $\Delta \Delta \mathrm{Ct}$ values were finally converted to fold differences using the formula: fold difference $=2^{(-\Delta \Delta C t)}$.

\section{Statistical analyses}

Results for hormone secretion (during final 96-144 h period of culture) were analysed using two-way ANOVA and are presented as means \pm SEM based on four independent culture experiments. To reduce heterogeneity of variance, hormone data were log-transformed prior to statistical analysis. qRT-PCR data (from $\mathrm{n}=4$ independent granulosa cell batches) were statistically analysed (ANOVA and post-hoc Fisher's LSD test) as $\Delta \mathrm{Ct}$ values before conversion to fold-difference values for graphical presentation.

\section{Microarray}

Following confirmation of the quality of the RNA and cDNA synthesis, hybridisations to GeneChip ${ }^{\oplus}$ Bovine
Genome Arrays (Affymetrix, CA, USA) and scanning were performed according to Affymetrix protocols at the Almac Diagnostics Facility. All samples were analysed together as one lot using the same batch of arrays. First-strand cDNA synthesis was performed on two micrograms of RNA using a T7-linked oligo-dT primer, followed by second strand synthesis. In vitro transcription reactions were performed in batches to generate biotinylated cRNA targets, which were subsequently chemically fragmented at $95^{\circ} \mathrm{C}$ for $35 \mathrm{~min}$. Ten $\mu \mathrm{g}$ of the fragmented, biotinylated cRNA was hybridized at $45^{\circ} \mathrm{C}$ for $16 \mathrm{~h}$ to Affymetrix GeneChip Bovine Genome Arrays, which contain 24,128 probe sets representing over 23,000 transcripts and variants, including 19,000 UniGene clusters. The arrays were then washed and stained with streptavidin-phycoerythrin (final concentration $10 \mu \mathrm{g} / \mathrm{ml}$ ). Signal amplification was achieved by using a biotinylated anti-streptavidin antibody. The array was then scanned according to the manufacturer's instructions. The scanned images were inspected for the presence of any defect (artefact or scratch) on the array.

\section{Treatment and analysis of microarray data}

Non-biological signal variation due to possible array differences or hybridisation treatments were minimised by normalisation of the raw data using the Robust Multi-array Average (RMA) method [42,43] with adjustments as detailed previously $[44,45]$. The normalisation and statistical analyses were performed in Partek Genomics Suite Software version 6.5 (Partek Incorporated, St Louis, MO, USA). Array quality controls were performed by spike-in analysis of standard amounts of bacterial specific cDNA against respective homologous probe sets on the chip. Statistical differences between treatment groups were determined by one-way ANOVA with FDR tests for multiple comparisons. The fold change in gene expression was determined from the non log-transformed signal data after correction and normalisation. The experimental details and array CEL data files have been deposited under series name GSE42535 in NCBI's Gene Expression Omnibus (GEO) database. 


\section{Network and functional analysis}

The groups of differentially expressed genes were uploaded into the Ingenuity Pathway Analysis (IPA) database for network and pathway determination (Ingenuity Systems, 2005). These datasets were also characterised according to their association with Gene Ontology (GO) terms listed under biological process using Gene Ontology Enrichment Analysis Software Toolkit (GOEAST) [46].

\section{Additional files}

Additional file 1: Figure S1. Unsupervised hierarchical clustering across all probe sets $(n=24,182)$ for 16 arrays using the Euclidian dissimilarity algorithm with the average linkage method in Partek Genomics Suite. The heatmap represents the distribution of normalised signal intensity, grouped by pattern similarity for both probe set and array (indicated by dendrogram at top).

Additional file 2: Figure S2. Principal component analyses of probe set intensity for all TNFa treatment arrays $(n=8)$ A, and FSH-treated and control arrays $(n=7)$ B. In A the arrays are numbered TNFa-treated (G3, G7, G11 and G15 in red) and TNFa plus FSH-treated (G4, G8, G12, and $\mathrm{G} 16$ in black). In $B$, the arrays are numbered ( $n=4$ per treatment) as follows: control granulosa (G1, G5, G9 and G13 in grey); FSH-treated (G2, G6, G10 and G14 in blue). The graph is a scatter plot of the values for the first $(X)$ and second $(Y)$ principal components based on the correlation matrix of the total normalised array intensity data.

Additional file 3: Figure S3. Venn diagram of numbers of genes differentially regulated between TNFa \pm FSH treatments and the control. Symbols indicate genes which are up $(\uparrow)$ and down regulated $(\downarrow)$.

Additional file 4: Table S1. The numbers of probe sets which were differentially regulated between TNFa \pm FSH treatments of cultured granulosa and the control. The numbers were determined by a one-way ANOVA with an FDR of $P<0.05$ for multiple comparisons using Partek.

Additional file 5: Table S2. A list of probe sets $(n=527)$ which are 3-fold differentially regulated between control $( \pm$ FSH) $(n=7)$ and TNFa $( \pm$ FSH)-treated $(n=8)$ groups with an FDR of $P<0.05$ for multiple comparisons. The probe sets are listed in alphabetical order based on gene symbol, and those which have not been assigned a gene annotation have been placed at the end of the list.

\section{Abbreviations}

FSH: Follicle-stimulating hormone; LH: Luteinising hormone; TGF $\beta$ : Transforming growth factor beta; TNFa: Tumour necrosis factor alpha; qRT-PCR: Quantitative reverse transcription polymerase chain reaction; PCA: Principal component analysis; FDR: Benjamini-Hochberg false discovery rate; GO: Gene ontology; GOEAST: Gene ontology enrichment analysis software toolkit; GEO: Gene expression omnibus; IPA: Ingenuity pathway analysis; NCBI: National centre for biotechnology information; RMA: Robust multi-array average; LSD: Least significant difference; CV: Coefficient of variation.

\section{Competing interests}

The authors declare that they have no competing interests.

\section{Authors' contributions}

Conceived and designed the experiments: PGK, CG and RJR. Performed the experiments: CG, PGK and RJR. Analysed the data: NH, KH, CG, PGK and RJR. Wrote the paper: $\mathrm{NH}, \mathrm{KH}, \mathrm{CG}, \mathrm{PGK}$ and RJR. All authors read and approved the final manuscript.

\section{Acknowledgements}

This work was supported by the United Kingdom Biotechnology and Biological Sciences Research Council (grant no. BB/G017174/1 to PGK and CG and Underwood Fellowship award to RJR) and by the National Health and Medical Research Council of Australia and the Australian Research Council ( $\mathrm{NH}, \mathrm{KH}$ and RJR).

\section{Author details}

${ }^{1}$ School of Biological Sciences, University of Reading, Hopkins Building, Reading RG6 6UB Whiteknights, UK. ²Discipline of Obstetrics and Gynaecology, School of Paediatrics and Reproductive Health, Robinson Institute, University of Adelaide, 5005 Adelaide, SA, Australia.

Received: 30 June 2013 Accepted: 22 January 2014

Published: 28 January 2014

\section{References}

1. Rodgers RJ, Irving-Rodgers HF, Van Wezel IL, Krupa M, Lavranos TC: Dynamics of the membrana granulosa during expansion of the ovarian follicular antrum. Mol Cell Endocrino/ 2001, 171(1-2):41-48.

2. Rodgers RJ, Irving-Rodgers HF: Formation of the ovarian follicular antrum and follicular fluid. Biol Reprod 2010, 82(6):1021-1029.

3. Ginther OJ, Wiltbank MC, Fricke PM, Gibbons JR, Kot K: Selection of the dominant follicle in cattle. Biol Reprod 1996, 55(6):1187-1194.

4. Fortune JE, Sirois J, Turzillo AM, Lavoir M: Follicle selection in domestic ruminants. J Reprod Fertil Supp/ 1991, 43:187-198.

5. Ginther OJ, Bergfelt DR, Beg MA, Kot K: Follicle selection in cattle: relationships among growth rate, diameter ranking, and capacity for dominance. Biol Reprod 2001, 65(2):345-350.

6. Manikkam M, Calder MD, Salfen BE, Youngquist RS, Keisler DH, Garverick HA: Concentrations of steroids and expression of messenger RNA for steroidogenic enzymes and gonadotropin receptors in bovine ovarian follicles of first and second waves and changes in second wave follicles after pulsatile LH infusion. Anim Reprod Sci 2001, 67(3-4):189-203.

7. Beg MA, Bergfelt DR, Kot K, Wiltbank MC, Ginther OJ: Follicular-fluid factors and granulosa-cell gene expression associated with follicle deviation in cattle. Biol Reprod 2001, 64(2):432-441.

8. Dong J, Albertini DF, Nishimori K, Kumar TR, Lu N, Matzuk MM: Growth differentiation factor- 9 is required during early ovarian folliculogenesis. Nature 1996, 383(6600):531-535.

9. Otsuka F, Yao Z, Lee T, Yamamoto S, Erickson GF, Shimasaki S: Bone morphogenetic protein-15. Identification of target cells and biological functions. J Biol Chem 2000, 275(50):39523-39528.

10. Van Wezel IL, Dharmarajan AM, Lavranos TC, Rodgers RJ: Evidence for alternative pathways of granulosa cell death in healthy and slightly atretic bovine antral follicles. Endocrinology 1999, 140(6):2602-2612.

11. Boehning D, Patterson RL, Sedaghat L, Glebova NO, Kurosaki T, Snyder SH: Cytochrome $\mathrm{c}$ binds to inositol $(1,4,5)$ trisphosphate receptors, amplifying calcium-dependent apoptosis. Nat Cell Biol 2003, 5(12):1051-1061.

12. Hsu H, Shu HB, Pan MG, Goeddel DV: TRADD-TRAF2 and TRADD-FADD interactions define two distinct TNF receptor 1 signal transduction pathways. Cell 1996, 84(2):299-308.

13. Sasson R, Amsterdam A: Stimulation of apoptosis in human granulosa cells from in vitro fertilization patients and its prevention by dexamethasone: involvement of cell contact and bcl-2 expression. J Clin Endocrinol Metab 2002, 87(7):3441-3451.

14. Basini G, Mainardi GL, Bussolati S, Tamanini C: Steroidogenesis, proliferation and apoptosis in bovine granulosa cells: role of tumour necrosis factor-alpha and its possible signalling mechanisms. Reprod Fertil Dev 2002, 14(3-4):141-150.

15. Sakumoto R, Shibaya M, Okuda K: Tumor necrosis factor-alpha (TNF alpha) inhibits progesterone and estradiol-17beta production from cultured granulosa cells: presence of TNFalpha receptors in bovine granulosa and theca cells. J Reprod Dev 2003, 49(6):441-449.

16. Matsuda F, Inoue N, Manabe N, Ohkura S: Follicular growth and atresia in mammalian ovaries: regulation by survival and death of granulosa cells. J Reprod Dev 2012, 58(1):44-50.

17. Glister C, Tannetta DS, Groome NP, Knight PG: Interactions between follicle-stimulating hormone and growth factors in modulating secretion of steroids and inhibin-related peptides by nonluteinized bovine granulosa cells. Biol Reprod 2001, 65(4):1020-1028.

18. Glister C, Richards SL, Knight PG: Bone morphogenetic proteins (BMP) $-4,-6$, and -7 potently suppress basal and luteinizing hormone-induced androgen production by bovine theca interna cells in primary culture: could ovarian hyperandrogenic dysfunction be caused by a defect in thecal BMP signaling? Endocrinology 2005, 146(4):1883-1892. 
19. Kayani AR, Glister C, Knight PG: Evidence for an inhibitory role of bone morphogenetic protein(s) in the follicular-luteal transition in cattle. Reproduction 2009, 137(1):67-78.

20. Kaipia A, Chun SY, Eisenhauer K, Hsueh AJ: Tumor necrosis factor-alpha and its second messenger, ceramide, stimulate apoptosis in cultured ovarian follicles. Endocrinology 1996, 137(11):4864-4870.

21. Price JC, Bromfield JJ, Sheldon IM: Pathogen-associated molecular patterns initiate inflammation and perturb the endocrine function of bovine granulosa cells from ovarian dominant follicles via TLR2 and TLR4 pathways. Endocrinology 2013, 154(9):3377-3386.

22. Hillier SG, Whitelaw PF, Smyth CD: Follicular oestrogen synthesis: the 'two-cell, two-gonadotrophin' model revisited. Mol Cell Endocrinol 1994, 100(1-2):51-54

23. Scaramuzzi RJ, Baird DT, Campbell BK, Driancourt MA, Dupont J, Fortune JE, Gilchrist RB, Martin GB, McNatty KP, McNeilly AS, et al: Regulation of folliculogenesis and the determination of ovulation rate in ruminants. Reprod Fertil Dev 2011, 23(3):444-467.

24. Anttonen M, Parviainen H, Kyronlahti A, Bielinska M, Wilson DB, Ritvos O, Heikinheimo M: GATA-4 is a granulosa cell factor employed in inhibin-alpha activation by the TGF-beta pathway. J Mol Endocrinol 2006, 36(3):557-568

25. Okuda T, Mita S, Yamauchi S, Fukuta M, Nakano H, Sawada T, Habuchi O: Molecular cloning and characterization of GalNAc 4-sulfotransferase expressed in human pituitary gland. J Biol Chem 2000, 275(51):40605-40613.

26. Stanton PG, Burgon PG, Hearn MT, Robertson DM: Structural and functional characterisation of $\mathrm{hFSH}$ and $\mathrm{hLH}$ isoforms. Mol Cell Endocrinol 1996, 125(1-2):133-141.

27. Wide $L$, Eriksson $K$, Sluss PM, Hall JE: Serum half-life of pituitary gonadotropins is decreased by sulfonation and increased by sialylation in women. J Clin Endocrinol Metab 2009, 94(3):958-964.

28. Lee $C L$, Pang PC, Yeung WS, Tissot B, Panico M, Lao TT, Chu IK, Lee KF, Chung MK, Lam KK, et al: Effects of differential glycosylation of glycodelins on lymphocyte survival. J Biol Chem 2009, 284(22):15084-15096.

29. Herath S, Williams EJ, Lilly ST, Gilbert RO, Dobson H, Bryant CE, Sheldon IM: Ovarian follicular cells have innate immune capabilities that modulate their endocrine function. Reproduction 2007, 134(5):683-693.

30. Bromfield JJ, Sheldon IM: Lipopolysaccharide initiates inflammation in bovine granulosa cells via the TLR4 pathway and perturbs oocyte meiotic progression in vitro. Endocrinology 2011, 152(12):5029-5040.

31. Hara S, Takahashi T, Amita M, Igarashi H, Tsutsumi S, Kurachi H: Bezafibrate restores the inhibition of $\mathrm{FSH}$-induced follicular development and steroidogenesis by tumor necrosis factor-alpha through peroxisome proliferator-activated receptor-gamma pathway in an in vitro mouse preantral follicle culture. Biol Reprod 2011, 85(5):895-906.

32. Ignatova ID, Kostadinova RM, Goldring CE, Nawrocki AR, Frey FJ, Frey BM: Tumor necrosis factor-alpha upregulates 11 beta-hydroxysteroid dehydrogenase type 1 expression by CCAAT/enhancer binding protein-beta in HepG2 cells. Am J Physiol Endocrinol Metab 2009, 296(2):E367-E377.

33. Agnihotri N, Kumar S, Mehta K: Tissue transglutaminase as a central mediator in inflammation-induced progression of breast cancer. Breast cancer research : BCR 2013, 15(1):202.

34. Monk PN, Scola AM, Madala P, Fairlie DP: Function, structure and therapeutic potential of complement $\mathrm{C} 5$ a receptors. British journal of pharmacology 2007, 152(4):429-448.

35. Bingle $C D$, Vyakarnam A: Novel innate immune functions of the whey acidic protein family. Trends in immunology 2008, 29(9):444-453.

36. Scott A, Weldon S, Taggart CC: SLPI and elafin: multifunctional antiproteases of the WFDC family. Biochemical Society transactions 2011, 39(5):1437-1440

37. Midwood KS, Orend G: The role of tenascin-C in tissue injury and tumorigenesis. Journal of cell communication and signaling 2009, 3(3-4):287-310.

38. Glister C, Kemp CF, Knight PG: Bone morphogenetic protein (BMP) ligands and receptors in bovine ovarian follicle cells: actions of BMP-4, -6 and -7 on granulosa cells and differential modulation of Smad-1 phosphorylation by follistatin. Reproduction 2004, 127(2):239-254.

39. Tannetta DS, Feist SA, Bleach EC, Groome NP, Evans LW, Knight PG: Effects of active immunization of sheep against an amino terminal peptide of the inhibin alpha $C$ subunit on intrafollicular levels of activin $A$, inhibin $A$ and follistatin. J Endocrinol 1998, 157(1):157-168.
40. Bleach EC, Glencross RG, Feist SA, Groome NP, Knight PG: Plasma inhibin A in heifers: relationship with follicle dynamics, gonadotropins, and steroids during the estrous cycle and after treatment with bovine follicular fluid. Biol Reprod 2001, 64(3):743-752.

41. Livak KJ, Schmittgen TD: Analysis of relative gene expression data using real-time quantitative PCR and the 2(-Delta Delta C(T)) Method. Methods 2001, 25(4):402-408.

42. Bolstad BM, Irizarry RA, Astrand M, Speed TP: A comparison of normalization methods for high density oligonucleotide array data based on variance and bias. Bioinformatics 2003, 19(2):185-193.

43. Irizarry RA, Hobbs B, Collin F, Beazer-Barclay YD, Antonellis KJ, Scherf U, Speed TP: Exploration, normalization, and summaries of high density oligonucleotide array probe level data. Biostatistics 2003, 4(2):249-264.

44. Hatzirodos N, Irving-Rodgers HF, Hummitzsch K, Harland ML, Morris SE, Rodgers RJ: Transcriptome profiling of granulosa cells of bovine ovarian follicles during growth from small to large antral sizes. BMC Genomics 2014, 15(1):40

45. Hatzirodos N, Hummitzsch K, Irving-Rodgers HF, Harland ML, Morris SE, Rodgers RJ: Transcriptome profiling of granulosa cells from bovine ovarian follicles during atresia. BMC Genomics 2014, 15(1):24.

46. Zheng Q, Wang XJ: GOEAST: a web-based software toolkit for Gene Ontology enrichment analysis. Nucleic Acids Res 2008, 36:W358-363.

doi:10.1186/1471-2164-15-72

Cite this article as: Glister et al:: The global effect of follicle-stimulating hormone and tumour necrosis factor a on gene expression in cultured bovine ovarian granulosa cells. BMC Genomics 2014 15:72.

\section{Submit your next manuscript to BioMed Central and take full advantage of:}

- Convenient online submission

- Thorough peer review

- No space constraints or color figure charges

- Immediate publication on acceptance

- Inclusion in PubMed, CAS, Scopus and Google Scholar

- Research which is freely available for redistribution

Submit your manuscript at www.biomedcentral.com/submit
C) Biomed Central 